\title{
AcE-Bs2021KotaBharu
}

https://www.amerabra.org; https://fspu.uitm.edu.my/cebs; https://www.emasemasresources.com/ $9^{\text {th }}$ Asian Conference on Environment-Behaviour Studies Perdana Kota Bharu, Kelantan, Malaysia, 28-29 Jul 2021

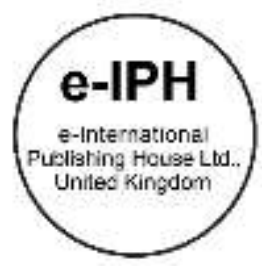

\section{Eco-Business Practices among Malaysian Green Technology Companies towards Expected Business Benefits}

\author{
Siti Zahrah Buyong, Sharifah Zannierah Syed Marzuki, \\ Junainah Junid, Mohd Ali Bahari Abdul Kadir \\ Faculty of Business and Management \\ Universiti Teknologi MARA, Puncak Alam, Selangor Darul Ehsan, Malaysia \\ siti280@uitm.edu.my, szannierah@uitm.edu.my,junainahjunid@uitm.edu.my,mohda419@uitm.edu.my \\ Tel: $+603-32587042$
}

\begin{abstract}
In Malaysia, environmental issues are increasing and achieving environmental consciousness, d business success is very challenging. This research aims to know the relationship between regulations, customer pressure, and social responsibility towards expected business benefits. The convenience sampling method was conducted to companies listed under Greentech provided by Malaysia External Trade Corporation (MATRADE). It is gathered from the findings that regulations, customer pressure, and social responsibility appeared to significantly affect relationship towards expected business benefits. This research has an overall output as the findings serve as a vital component to facilitate the business operating system from the green practices.
\end{abstract}

Keywords: eco-business; Malaysian; green;companies

eISSN: 2398-4287@ 2021. The Authors. Published for AMER ABRA cE-Bs by e-International Publishing House, Ltd., UK. This is an open access article under the CC BYNCND license (http://creativecommons.org/licenses/by-nc-nd/4.0/). Peer-review under responsibility of AMER (Association of Malaysian Environment-Behaviour Researchers), ABRA (Association of Behavioural Researchers on Asians/Africans/Arabians) and cE-Bs (Centre for Environment-Behaviour Studies), Faculty of Architecture, Planning \& Surveying, Universiti Teknologi MARA, Malaysia.

DOI: https://doi.org/10.21834/ebpj.v6i17.2826

\subsection{Introduction}

Sustainability has become a widely discussed topic among corporates, politicians, and academia (Mohrman \& Worley, 2010). The UN Sustainable Development Goals (SDGs) introduced in 2015 act as a blueprint to sustainably and invigorate sustainability. One of the definitions of sustainable development is "development that meets the needs of the present without compromising the ability of future generations to meet their own needs" (World Commission on Environment and Development, 1987, p.8), which took from the Brundtland Commission, introduced in the 1980s. This definition poses astute views compared to other earlier findings of sustainability which generally denotes the capability of upholding and retaining something in the presence (Marshall \& Toffel, 2005).

The definitions of sustainability have exceeded 100 by the middle of the 1990s (Elkington, 2003). Some scholars associated the situation with the Brundtland Commission's broad definition, complicating the organizations to ascertain their distinct roles within a more comprehensive perspective (Shrivastava \& Hart, 1995; Stead \& Stead, 1996). This is because sustainability has been the subject of interest by academics from multiple disciplines (Carter \& Rogers, 2008). Environmental sustainability is derived mainly from engineering literature that includes three main elements; environmental, social, and economic.

Here, sustainability is seen as having a sensible balance between environmental concern, social obligation, and economic development (Sikdar, 2003, p. 1928), and having a balanced focus for economic stability, ecological compatibility, and social equilibrium (Go'ncz et al., 2007).

eISSN: 2398-4287@ 2021. The Authors. Published for AMER ABRA cE-Bs by e-International Publishing House, Ltd., UK. This is an open access article under the CC BYNCND license (http://creativecommons.org/licenses/by-nc-nd/4.0/). Peer-review under responsibility of AMER (Association of Malaysian Environment-Behaviour Researchers), ABRA (Association of Behavioural Researchers on Asians/Africans/Arabians) and CE-Bs (Centre for Environment-Behaviour Studies), Faculty of Architecture, Planning \& Surveying, Universiti Teknologi MARA, Malaysia.

DOI: https://doi.org/10.21834/ebpj.v6i17.2826 
As the definition of environmental sustainability evolved and increasingly well-defined, organizations became more concerned with environmental sustainability. As a result, various parties have launched and implemented countless innovative initiatives, including the public sector, private organizations, and the third sector, to help reduce the adverse impact of human activity towards mother nature. Furthermore, it is to improve the well-being of societies as organizations decided to embark on sustainable ways on how they do business to the extent that is amending and adapting their business model to fit with the growing concern of making the future more sustainable for all. They are, in fact committing themselves to a different way of operating that considers the ecosystem of which they are a part and upon which they depend (Mohrman \& Worley, 2010).

The objective of study is to investigate the adaptation of the eco-business model among certified Small and Medium Enterprises (SME) companies in Malaysia that consider four elements: regulation, customer pressure, social responsibility, and expected benefits deemed to sustain the environment. It will underline organizations' commitment to implement sustainable ways, i.e., business model, the strategies and plans they have crafted to achieve their "green goal" hence support the UN SDGs in the long run. It is important to note that the literature on eco business practices in Malaysia is very sparse as not many businesses are ready and capable to apply green practices that involves certain costs.

\subsection{Factors Contributing to Environmental Sustainability}

\subsection{Regulation}

Environmental issues are increasing not only in Malaysia, but it is a severe problem worldwide. It is challenging for business organizations due to these environmental problems (Eltayeb, Zailani \& Ramayah, 2011). Eco-Industrial Parks (EIPs) have contributed symbiotic relationships to curb the ecological issues by improving the resource productivity and eco-efficiency of production and consumption (Behera, Kim, Lee, Suh \& Park, 2012; Lehtoranta, Nissinen, Mattila, Melanen, 2011). However, Sakr, Baas, and Huisingh (2011) have argued that although many industries have taken necessary actions to address environmental pollution, most industrial estates have not systematically addressed pollution. The problem that has been raised is on explicit environmental management capability or environmental plan.

Previous research reiterates that business operations are the primary source of the growing pressures for these problems, including air pollution, water pollution, environmental degradation, and water disposal. The world is facing a difficult situation concerning environmental issues that include global warming and ozone depletion. In Malaysia, environmental issues are also increasing and achieving environmental consciousness and business success is challenging.

The Environmental Quality Act 1974 is set to ensure that regulations are at placed as the country moves to become an industrialized nation. Looking at the regulations, it is stated that $87 \%$ of previous studies found that it is a significant driver in adopting green practices (Buysse \& Verbeke, 2003; Christmann \& Taylor, 2001; Levy, 1995). Within this context, regulations consist of environmental rules and procedures where companies must implement green practices to alleviate environmental issues, as discussed above. As Malaysia is a developing country, it is clear that the pressure from developed countries predominantly influences the key activities of the manufacturing companies as what is happening in China. Zhu and Sarkis (2004) highlighted that China had imposed strong environmental regulations for local manufacturers to perform green practices.

\subsection{Customer Pressure}

Green competitivenesss is so prevalent that it surpasses business (Omar, Othman \& Jabar, 2017). As discussed earlier environmental pollution, industrial development, and rapid urbanization are significant contributors to the said problem. Adopting green practices is very substantial to enhance organizations' sustainability development, thus achieving competitive advantage by reducing costs or offering product varieties. Apart from regulation to be enforced by organizations in eco-design initiatives, customer pressure can also influence environmental performance, which appears to be the most cited driver along with legislation (Yu, Hills \& Welford, 2008).

A cross-country study on drivers and outcomes of eco-design initiatives in Malaysia and Australia by Iranmanesh, Fayezi, Hanim, and Sean Hyun (2018) found different roles in customer pressure and business benefits on eco-design initiatives between Malaysia and Australia. They revealed that customer pressure has no impact even though business benefits significantly impact eco-design initiatives.

In contrast, customer pressure relates to eco-design initiatives in Australia. This shows that Malaysian manufacturers are more concerned about costs as far as eco-design is concerned. In contrast, customer pressure has influenced manufacturers in Australia to adopt eco-design initiatives.

\subsection{Corporate Social Responsibility and Environmental Sustainability}

Corporate social responsibility (CSR) emerged and gradually gained popularity during the 1960s (McWilliams et al. 2006). This era was about social movement initiatives based on societal predicaments arising from various environmental, social, and community. The emphasis of CSR is towards corporate charity, stewardship principles, sponsorship for social and ecological reasons, employees' volunteerism, and community initiatives (Camileri, 2017), which exhibit the multiple facets characteristics of CSR in society (Walton, 1967).

CSR is not merely about addressing societal issues. It is also how an organization sees and acts on opportunity via innovation and its winning strategy (Porter \& Kramer, 2006), transparent in delivering its marketing messages, fulfilling obligations towards stakeholders, and performing philanthropic behaviors (Singh \& Del Bosque, 2008). Socially responsible businesses distinguish themselves from their competitors by leveraging on the company's image comparative to others, thus help to reap reputational benefits and create a desirable state of trust, cooperation, and teamwork within the company (Camilleri 2014). 
Therefore, companies that embark on CSR envision a holistic strategy by considering stakeholders' expectations and the 'triple bottom line' of economic, social, and environmental performance.

In recent years companies' involvement in CSR is growing and no longer uncommon, especially in developed and developing countries. Increasing concern on environmental issues combined with reputational benefits and marketing image-making CSR a necessity for companies. Pressure from stakeholders for companies to engage in CSR forces business executives to become more adept at integrating their organization's market and non-market strategies (Baron, 2001) and strategize how to implement social responsibilities more effectively to promote environmental sustainability. Businesses have adopted various methods to implement CSR effectively, and one of the strategies is adopting the eco-business model and green management practices.

\subsection{Expected Business Benefits}

One should understand the meaning of the term eco-business towards a deeper understanding of the benefits to SMEs that practice ecobusiness. It can be interpreted that when a company takes comprehensive measures to reduce the negative impact on the environment, it adopts an eco-business. This positive effect can be seen when the company is re the utility costs of their business operation. On the other hand, practicing the recycling process using the company's waste can also be categorized as a benefit to the SME, ultimately providing a healthy business environment. Recognizing the eco-business model will ensure the sustainability of SMEs across the globe. Identifying and practicing the key business driver will bring many benefits to SME (Eltayeb et al., 2010; Mustapha et al., 2017). The main issue is a growing number of SMEs are keen to get certified sustainable but confronted with complex processes which involve high costs. Sustainability experts among the regulator and practitioner play an essential role in advising on what SMEs can do to achieve this objective (Iranmanesh et al., 2019). Multinational companies operating in Malaysia have been recognized as green companies. They are a good example of their concern for the environment by reducing their carbon footprints are Procter \& Gamble, Puma, IKEA, Home Depot, Nike, Apple, Toms, and Amazon.

The involvement of environment, social and economic are the three components describing SMEs sustainability. SMEs can achieve this objective via employee engagement in finding ways to improve resource efficiency.

The Six Benefits that can be obtained through the eco-business model are as follows:

- $\quad$ Reduce Energy-Related Costs. Energy and air costs are identified as a significant concern of manufacturers. Using alternative energy sources and fuels such as fossils in factory waste recycling activities will produce efficiency. A small number of pollutants is released into the environment (Canning \& Hanmer-Lloyd, 2001). Here, they should allocate money to carry out green business procedures; it is beneficial to save money over time. United Airlines, for example, is developing a partnership with AltAir Fuels in the use of sustainable biojet fuels. Buying renewable low-carbon fuel allows their airlines to compete and enable United Airlines to reduce overall costs.

- $\quad$ Attract more customers by penetrating new markets resulting in increased productivity, reduced costs, and increased sales. It will also enhance its image and competitive advantage (Buhl, Blazejewski \& Dittmer, 2016). The increasingly green industry makes customers feel that it is a trustworthy business. Through a survey of 30,000 consumers worldwide in 2015, Nielsen stated that 66 percent of consumers agree that they are willing to pay more for a product from a sustainable source. The same survey was conducted again where the study's findings showed that the results jumped to 77 percent among Millennial users. Companies should pay attention to consumers who appreciate and trust eco-friendly.

- $\quad$ Social Impact. The direct involvement of more companies in sustainable business will also create more job opportunities and produce high-quality staff in their work quality. This effort will provide various benefits in reducing the unemployment rate in Malaysia, reducing poverty, and further improving the community's living standards. Practicing this green environment will later give awareness of the importance of practicing in their environment and even provide benefits in a healthy environment. Society can also be educated to reuse used products and dispose of end-of-life products properly (Fernando, Jabbour, \& Wah, 2019). This, in turn, helps solve problems related to environmental challenges around the world.

- Tax Incentives. The Malaysian government provides tax incentives to SMEs to purchase green technology and companies that use green technology services in their business. With this tax incentive, SMEs are hoping to expand the Renewable Energy market. Malaysian Green Technology Corporation in 2019 introduced the Green Technology TAx includes Green Investment Tax Allowance Assets (GITA), Green Investment Tax Allowance Project (GITA), and Green Income Tax Exemption Service (GITE).

- Improve morale and workforce where it can improve recruitment and retention of quality employees in the company. Employees feel safer working in a green business where their health is taken care of by the employer. This can directly reduce employee turnover as they think they are part of a caring work community.

- Healthier work environment. Being green will also maintain a healthy environment by reducing soil, air, and water pollution. This can help solve environmental challenges worldwide, such as global warming and lack of resources.

\subsection{Methodology}

A total of 14 questionnaires were distributed to the owners of certified companies of Greentech listed by Malaysia External Trade Development Corporation (MATRADE). The researchers have used convenience sampling as the response to fill in the questionnaire was not that impressive. The number is relatively small, taking the pandemic health issue as the contributing factor. The initial plan was to administer the questionnaires to the respondents in person but changed to disseminating them online using Google form. The items in the questionnaire are adopted and adapted from previous researches. Partial least-square structural equation modeling (PLS_SEM) using the 
Smart PLS 3.0 software was conducted to validate measures. This study is to measure the relationship of latent variables using convergent validity and discriminant analysis.

Table 1: Sample of Item measurement

\begin{tabular}{|c|c|}
\hline Regulation & $\begin{array}{l}\text { Our firm has to comply with the environmental regulation } \\
\text { Penalties will be imposed if our firm does not comply with the environmental } \\
\text { regulation } \\
\text { An environmental inspection is carried out in our firm periodically } \\
\text { Our staffs are aware with the environmental regulation }\end{array}$ \\
\hline Customer Pressure & $\begin{array}{l}\text { Customer pressure leads to improvement of environmental sustainability } \\
\text { Customer pressure leads to sustainability of environmental performance } \\
\text { Customer pressure is a useful mean in developing green practices } \\
\text { Customer pressure is an external driver for eco-business works concurrently } \\
\text { with the regulation }\end{array}$ \\
\hline Social Responsibility & $\begin{array}{l}\text { Our firm adapts green practices during its daily operations } \\
\text { Our firm is engaged to voluntary commitment to the community } \\
\text { Our firm builds acceptable image to the society } \\
\text { Our firm builds a good reputation to the society } \\
\text { Our firm produces environmentally friendly products }\end{array}$ \\
\hline $\begin{array}{l}\text { Expected Business } \\
\text { Benefits }\end{array}$ & $\begin{array}{l}\text { Our firm has deployed latest green technology } \\
\text { Our firm continuously exploits the potential of technology } \\
\text { Our firm has set up in house R\&D unit } \\
\text { Our firm has made greater use of green technology }\end{array}$ \\
\hline
\end{tabular}

\subsection{Findings}

Demographic profiling of the firms is shown in Table 2 where most of the companies are less than 15 years of age $(n=13,92.9 \%)$. The highest percentage in the number of employees is less than $100(n=11,78.6 \%)$ and the least is $100-250$ employees $(n=1,7.1 \%)$. It is gathered that $(n=11,78.6 \%)$ of the respondents produce consumer products and the remaining of $(n=3,21.4 \%)$ manufacture industrial products. Majority of the companies fall under private limited company $(n=9,64.3 \%)$, enterprise $(n=3,21.4 \%)$ and public listed company $(n=2,14.3 \%)$. Not all companies participate in green associations as only $(n=4,28.6 \%)$ participated and the rest $(n=10,71.4 \%)$ do not.

Table 2: Demographic Profiling

\begin{tabular}{llcc}
\hline $\begin{array}{l}\text { Profile } \\
\mathrm{n}=14\end{array}$ & & Frequency & $\%$ \\
\hline Age of firm & $\begin{array}{l}\text { Less than 15 years } \\
\text { More than 15 years }\end{array}$ & 13 & 92.9 \\
& & 1 & 7.1 \\
\hline Number of employees & Less than 100 & 11 & 78.6 \\
& $100-250$ employees & 1 & 7.1 \\
& 251-520 employees & 2 & 14.3 \\
\hline Type of products & Consumer products & 11 & 78.6 \\
& Industrial products & 3 & 21.4 \\
\hline Ownership status & Enterprise & 3 & 21.4 \\
& Private limited company & 9 & 64.3 \\
& Public limited company & 2 & .3 \\
\hline
\end{tabular}




\subsection{Reliability Analysis}

Validity and reliability tests are vital for the goodness of measure. Internal consistency analysis (Cronbach a) was used to confirm the reliability of all research factors. The closer the Cronbach's alpha value is to one, the higher the consistent internal reliability (Sekaran, 2000). The results in Table 3 showed that Cronbach's a values for entire dimensions range from 0.893 to 0.933 , which exceeds the minimum a of 0.6 (Hair et al., 2006). Therefore, the measure of the constructs is regarded as reliable.

\begin{tabular}{lc}
\multicolumn{2}{c}{ Table 3: Cronbach a } \\
\hline Regulation & 0.893 \\
\hline Customer Pressure & 0.923 \\
\hline Social Responsibility & 0.908 \\
\hline Expected Business Benefits & 0.933 \\
\hline
\end{tabular}

\subsection{Reliability Analysis}

Validity and reliability tests are vital for the goodness of measure. Internal consistency analysis (Cronbach a) was used to confirm the reliability of all research factors. The closer the Cronbach's alpha value is to one, the higher the consistent internal reliability (Sekaran, 2000). The results in Table 3 showed that Cronbach's a values for entire dimensions range from 0.893 to 0.933 , which exceeds the minimum a of 0.6 (Hair et al., 2006). Therefore, the measure of the constructs is regarded as reliable.

\begin{tabular}{lc}
\multicolumn{2}{c}{ Table 3: Cronbach a } \\
\hline Regulation & 0.893 \\
\hline Customer Pressure & 0.923 \\
\hline Social Responsibility & 0.908 \\
\hline Expected Business Benefits & 0.933 \\
\hline
\end{tabular}

\subsection{Measurement Model}

According to Chin (2010), a measurement model or outer model poses the results in assessing the loadings, reliability, and validity of the measures used to represent each construct. This aligns with the method of PLS threshold values (Hair, Ringle and Sarstedt, 2011). It is shown in Table 4 that outer loadings of each variable are good loadings. Convergence validity is assessed through the extraction of factor loadings, composite reliability, and average variance (Hair et al., 2017). The composite reliability values in Table 4 indicated that they exceeded the recommended value of 0.7 (Hair et al., 2011). Furthermore, the average variance extracted by the latent construct also surpassed the suggested value of 0.5 (Hair et al., 2011). With this, the values of entire variables/constructs presented in the table appeared to have good levels of convergent validity. To test discriminant validity, the heterotrait-monotrait ratio of correlations (HTMT) was chosen.It is proven to be robust in testing discriminant analysis (Dijkstra \& Henseler, 2015). Again, Table 4 revealed that each variable's value is below 0.9 , and this shows that discriminant validity is substantiated.

Table 4: Reliability and Discriminant Analysis

\begin{tabular}{llllll} 
& CR & AVE & 1 & 2 & 3 \\
\hline Customer Pressure & 0.944 & 0.808 & & & \\
Expected Business Benefits & 0.952 & 0.833 & 0.672 & & \\
Regulations & 0.896 & 0.813 & 0.133 & 0.261 & \\
Social Responsibility & 0.928 & 0.72 & 0.483 & 0.538 & 0.305
\end{tabular}

\subsection{Structural Model}

Relationships between the constructs in the research model are examined by the structural model or inner model (Hair et al., 2017). A total of $60.2 \%$ of variance $\left(R^{2}\right)$ in expected business benefits showed a reliable predictive explanatory power of variance explained by antecedents of regulations, customer pressure, and social responsibility of eco-business benefits, as shown in Figure 1 . Regulations have a significant effect on expected business benefits $(\beta=0.278)$. Customer Pressure and social responsibility significantly affect expected business benefits with path $(\boldsymbol{\beta})$ coefficient of 0.525 and 0.262 , respectively, as in Table 5 . 


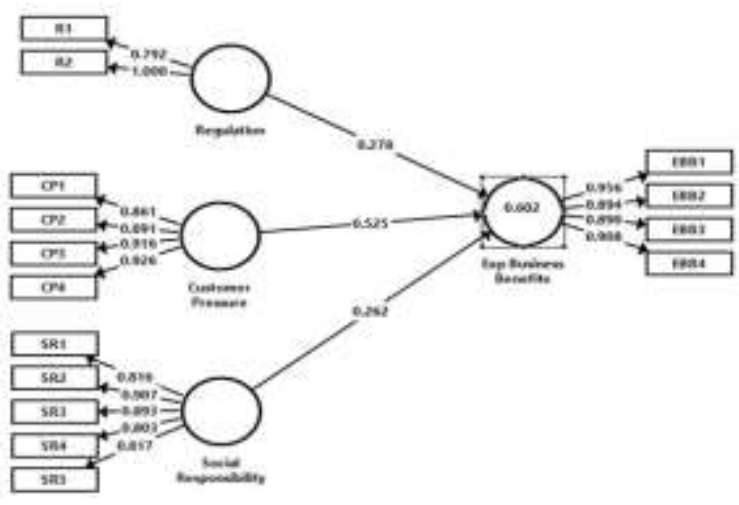

Figure 1: The Structural Model

\begin{tabular}{lc}
\multicolumn{2}{c}{ Table 5: Total Effect } \\
\hline Factors & $\beta$ \\
\hline Regulations - Expected Business Benefits & 0.278 \\
Customer Pressure - Expected Business Benefits & 0.525 \\
Social Responsibility - Expected Business Benefits & 0.262 \\
\hline
\end{tabular}

\subsection{Discussion}

Environmental problems are never-ending issues worldwide. Business operations face difficult situations concerning this. However, Sakr, Baas, and Huisingh (2011) have argued that although many industries have taken necessary actions to address environmental pollution, many industrial estates have not systematically fully addressed this issue. The problem that has been raised is on explicit environmental management capability or ecological plan.

This research is on environmentally conscious business (eco-business) towards the expected business benefits, including regulations, customer pressure, and social responsibility. The objective of this paper is to investigate the relationship of the factors mentioned earlier with business benefits. This study showed that most eco businesses are in the growth and expansion stage and running the businesses under private limited companies. Interestingly, the companies are producers of consumer products with less than 100 employees. It shows that with the number of low workers, the companies have the ability to sustain on the good practices and expected to increase the business benefits in the future. Thus, this study contributes to the body of knowledge.

\subsection{Conclusion \& Recommendations}

In this research, eco business is about the Malaysian SME companies that are applying eco-friendly/green practices, following the regulations, fulfilling customers' needs and wants and maintaining social responsibility. The findings revealed that regulations, customer pressure, and social responsibility significantly affect expected business benefits due to pressure from most developed countries. Not only that, customers seek companies to be able to provide green practices in their daily operations while maintaining the environment. Social responsibility appeared to be significant in influencing a company's business benefits, but it has the values of opportunity, innovation, and competitive advantage (Porter \& Kramer, 2006).

This empirical study also suggests that the policymakers consider policy, laws, and regulations regarding environmental issues due to manufacturing activities and environmental protection. Immediate actions should be initiated and brought to increase the eco-efficiency levels besides minimizing ecological liabilities. Some of the research limitations are the number of respondents who participated due to Movement Control Order (MCO) as face-to-face questionnaire distribution was unable to occur. Future research can look into Malaysian SME companies in the maturity stage or in the process of diversification. It is significant to note that companies that handle green practices or soon consider applying green initiatives will expect the business benefits to grow at an increasing rate where the factors mentioned above are essential.

\section{Acknowledgement}

The authors are grateful to the Institute of Research Management \& Innovation, Universiti Teknologi MARA (UiTM) for the awarded research grant with the project code: 600-IRMI 5/3/LESTARI (031/2018). Special thanks also go to all the respondents who have taken part in the survey despite the health issue of Covid 19. Finally, the authors are particularly thankful to the Faculty of Business and Management, UiTM, for the support given in completing this research. 


\section{Paper Contribution to Related Field of Study}

The study indicated that regulations, customer pressure and social responsibility directly relate to expected business benefits. Customers demand companies be able to deliver green practices in maintaining the environment. This research has a prevalent output as the findings serve as a vital component to facilitate the business operating system from the initiatives. The findings is significant to sustain the green environmental business situations and fulfill business services' aims in Economic Transformation Programme (ETP) in National Key Economic Areas (NKEA).

\section{References}

Behera, S. K., Kim, J-H., Lee, S-Y., Suh, S., \& Park, H-S. (2012). Evolution of 'designed' industrail symbiosis networks in the Ulsan eco-industrail park: 'research and development into business' as the enabling framework. Journal of Cleaner Production, 29-30, 103-112.

Buhl, A., Blazejewski, S., \& Dittmer, F. (2016). The more, the merrier: Why and how employee-driven eco-innovation enhances environmental and competitive advantage. Sustainability, 8(9), 946.

Buysse, K., \& Verbeke, A. (2003). Proactive environmental strategies: A stakeholder management perspective. Stratgeic Management Journal, 24(5), 453-470.

Camileri, M. A. (2017). Corporate sustainability and responsibility: Creating value for business, society and the environment. Asian Journal of Sustainability and Social Responsibility, 2(1), 59-74.

Canning, L., \& Hanmer-Lloyd, S. (2001). Managing the environmental adaptation process in supplier-customer relationships. Business Strategy and the Environment, 10(4), 225-237.

Carter, C. R., \& Rogers, D. S. (2008). A framework of sustainable supply chain management: moving toward new theory. International Journal of Physical Distribution \& Logistics Management, 38(5), $360-387$.

Christmann, P., \& Taylor, G. (2001). Globalization and the environment: Determinants of firm self-regulation in China. Journal of International Business Studies, 32(3), 439458.

Dijkstra, T. K., \& Henseler, J. (2015). Consistent and asymptotically normal PLS estimators for linear structural equations. Computational Statistics \& Data Analysis, 81, 1023.

Elkington, J. (2003). Sustainable developments: What is it? Sustainability at http: www.sustainability.com/philosophy/what-is-sustainable-development.asp. (accessed: January 12, 2021).

Eltayeb, T. K., Zailani, S., \& Ramayah, T. (2011). Green supply chain initiatives among certified companies in Malaysia and environmental sustainability: Investigating the outcomes. Resources, Conservation and Recycling, 55, 495-506.

Fernando, Y., Jabbour, C. J. C., \& Wah, W. X. (2019). Pursuing green growth in technology firms through the connections between environmental innovation and sustainable business performance: does service capability matter?. Resources, Conservation and Recycling, 141, 8-20.

Hair, J. F., Hollingsworth, C. L., Randolph, A. B., \& Chong, A. Y. L. (2017). An updated and expanded assessment of PLS-SEM in information systems research. Industrial Management \& Data Systems, 117(3), 442-458.

Iranmanesh, M., Fayezi, S., Hanim, S., \& Hyun, S. S. (2019). Drivers and outcomes of eco-design initiatives: a cross-country study of Malaysia and Australia. Review of Managerial Science, 13(5), 1121-1142.

Malaysian Green Technology Corporation. (2018). Guidelines for Green Technology Tax Incentive - Green Investment Tax Allowance (GITA) and Green Income Tax Exemption (GITE). MIDA, available at: www.mida.gov.my (accessed: November 26, 2020).

McWilliams, A., Siegel, D. S., \& Wright, P. M. (2006). Corporate social responsibility: strategic implications. J Manag Stud 43(1),1-18.

Mohrman, S.A., \& Worley, C.G. (2010). The Organizational Sustainability Journey: Introduction to the Special Issue. Organizational Dynamics, 4(39), 289-294.

Mustapha, M. A., Manan, Z. A., \& Alwi, S. R. W. (2017). Sustainable Green Management System (SGMS)-An integrated approach towards organisationa sustainability. Journal of Cleaner Production, 146, 158-172.

Omar, S., Othman, N. A., \& Jabar, J. (2017). Effect of Eco-Innovation Practices on Sustainable Business Performance. Pertanika J. Sci. \& Technol, 25 (S), 123-128.

Sakr, D., Baas, L., El-Haggar, S ., \& Huisingh, D. (2011). Critical success and limiting factors for eco-industrial parks: global trends and Egyptian context. Journal of Cleaner Production, 19, 1158-1169.

Sekaran, U. (2000). Research methods for business: A skill-building approach (3rded). New York: John Wiley \& Sons Inc.

Sikdar, S.K. (2003). Sustainable development and sustainability metrics. AIChE Journal, 49(8), 1928-32.

Singh, J., Sanchez, M. d. M. G. d. I. S., \& Bosque, I. R. d. (2008). Understanding Corporate Social Responsibility and Product Perceptions in Consumer Markets: A Crosscultural Evaluation. Journal of Business Ethics, 80, 597-611. 
World Commission on Environment and Development (1987). Our Common Future. Oxford University Press: Oxford, UK.

Zhu, Q., \& Sarkis, J. (2004). Relationships between operational practices and performance among early adopters of green suplly chain management practices in Chinese manufacturing enterprises. Journal of Operations Management, 22(3), 265-289. 